\title{
ALUR PELACAKAN PEMBALAKAN LIAR (ILLEGAL LOGGING) MELALUI PENDEKATAN PENCUCIAN UANG
}

\author{
Lucky Nurhadiyanto, S.Sos., M.Si
}

lucky.nurhadiyanto@budiluhur.ac.id

\begin{abstract}
Illegal logging is a part of crime against environment, which has a massive impact on the economy, social, cultural, and ecological. Ironically, majority of the illegal logging's perpetrators are dominated by "the field criminal". On the other side, intellectual actors who can control the activities never touch by the law. The money laundering concept can give a new approach to detect the leader actor. The author use follow the money viewpoint, which includes placement, layering, and integration. Qualitative data collection methods is used with in-depth interviews, systematic observation of the behavior, and document analysis. The result is a new paradigm in investigating illegal logging no longer focused on the field actors, but potentially tracking the intellectual actors behind illegal logging.
\end{abstract}

Keywords: Illegal Logging, Money Laundering, Placement, Layering, Integration.

\section{Pendahuluan}

Kejahatan lingkungan kian mendapatkan perhatian serius dalam kriminologi. Berkembanganya isu kejahatan lingkungan dalam perspektif green criminology menghadirkan ragam sudut pandang kajian kejahatan. Ancaman kejahatan lingkungan dapat berupa illegal destructive fishing, destructive mining, illegal logging, perburuan dan perdagangan satwa yang dilindungi (Colfer, dkk, 2008). Berbagai kejahatan lingkungan tersebut memiliki dampak jangka panjang terhadap keberlangsungan hidup ekosistem, salah satunya kejahatan di bidang kehutanan dalam bentuk pembalakan liar (illegal logging).
Pembalakan liar merupakan bagian dari kejahatan dalam bidang kehutanan. Namun, pembalakan liar dapat pula dipandang sebagai elemen rangkaian kejahatan dalam bidang kehutanan. Kejahatan dalam bidang kehutanan meliputi pelanggaran peraturan perundangundangan $^{1}$; pembalakan $\operatorname{liar}^{2}$; konversi hutan alam dengan melanggar ketentuan, dengan alasan untuk membangun perkebunan baru; perambahan hutan skala kecil, dengan menggunakan kelompok

\footnotetext{
${ }^{1}$ Tindak pidana kehutanan dalam bentuk ini dapat berwujud sebagai tindakan over-cutting, penyalahgunaan dokumen dan permasalahan perizinan kerap dimanipulasi untuk kepentingan tertentu.

2 Rangkaiannya meliputi pencurian kayu atau penebangan pohon tanpa izin (illegal logging), pengoperasian pabrik pengolahan kayu tak berizin, pengelolaan kayu ilegal, pengangkutan dan perdagangan kayu-kayu curian.
} 
masyarakat setempat; manipulasi peraturan perundang-undangan lingkungan; manipulasi dan penyalahgunaan kewenangan; dan penjarahan sumber daya hutan dalam arti luas ${ }^{3}$ (Alexander, 2006: 19-20).

Pembalakan liar perlu dikaji secara multidimensional meliputi aspek ekonomi, sosial, budaya dan ekologis. Indonesia menjadi negara dengan jumlah kasus pembalakan liar yang tinggi. Berdasarkan lansiran Kementerian Lingkungan Hidup dan Kehutanan (2016) sedikitnnya 1,1 juta hektar atau 2\% dari hutan Indonesia meyusut tiap tahunnya. Mengacu pada sumber yang sama, sekitar 130 juta hektar hutan yang tersisa, 42 juta hektar diantaranya sudah habis ditebang (WWF, 2016). Setiap tahunnya 51 juta $\mathrm{m}^{3}$ kayu dihasilkan dari pembalakan liar (Kementerian Lingkungan Hidup dan Kehutanan, 2016). Padahal di satu sisi, Indonesia berperan sebagai salah satu dengan penjaga kestabilan iklim dunia dengan kemampuan menyimpan 289 gigaton karbon. Berdasarkan hal tersebut, kerugian diperkirakan mencapai 50 triliun per tahunnya (Kementerian Lingkungan Hidup dan Kehutanan, 2016).

Dampak tersebut belum dikalkulasikan dengan kerugian ekosistem

3 Dipahami sebagai bentuk penguasaan yang sepihak dan bisnis tak berizin atas hasil-hasil non kayu (air, satwa, dan tumbuhan langka). yang ditimbulkan. Secara kasat, dampak dari pembalakan liar ini bisa terjadi segera maupun beberapa waktu kemudian. Pembalakan liar ditengarai sebagai penyebab banjir, kerusakan hutan dan ekosistemnya bahkan fenomena perubahan iklim dunia (Gatra, 2006). Tingginya tingkat karbon di atmosfer dapat menghambat pemantulan kembali sinar matahari keluar dari bumi karena gundulnya hutan yang berperan sebagai penyerap karbon terbesar di dunia (Nagara, 2007). Kondisi ini disebut dengan fenomena efek rumah kaca. fenomena ini dianggap bertanggung jawab dalam peningkatan suhu bumi yang menyebabkan mencairnya dua kutub es bumi (Sukardi, 2005:6). Pada akhirnya, hal ini dapat berakibat pada naiknya garis pantai dan tenggelamnya daratan pulau. Kondisi yang melahirkan isu internasional global warming (Al Gore, 2004).

Penggunaan pendekatan anti pencucian uang merupakan suatu terobosan dalam memberantas pembalakan liar. Selama ini, para pelaku di balik layar yang meliputi penyokong dana (financial backers), aktor intelektual dan para backing kayu dan illegal trade sulit terjamah hukum. Hal ini dikarenakan sulitnya menghadirkan barang bukti pengadilan (Alexander, 2006). Para aparat penegak hukum mengalami kesulitan membuktikan keterlibatan mereka dalam 
pembalakan liar (Tempo, 2005; Jikalahari, 2008). Semua kegiatan tersebut dilakukan oleh para pelaku di lapangan, seperti pembalak kayu, pemilik jasa angkutan yang dibayar dan orang bayaran lainnya (Husein, 2006). Mereka inilah yang kerap menjadi objek hukum kehutanan terkait pembalakan liar. Sementara, para aktor intelektual dapat lolos dari jerat hukum.

\section{Metodologi}

Penelitian ini menggunakan pendekatan kualitatif untuk menginterpretasikan pemahaman alur pelacakan hasil kejahatan pembalakan liar (illegal logging) melalui pendekatan pencucian uang. Pendekatan kualitatif digunakan untuk mengkaji dunia sosial melalui penekanan terhadap interpretasi pemahaman dan motivasi, melalui fenomena sosial dan budaya, perilaku individu, dan proses pengambilan keputusan (Kalof, dkk., 2008:79). Fenomea sosial penelitian ini adalah pembalakan liar. Pembalakan liar dikaji dengan menggunakan sudut pandang pendekatan pencucian uang. Hal ini terkait dengan peran penelitian kualitatif guna menggambarkan suatu fenomena dari sisi yang berbeda (Flick, dkk., 2004:3).

Teknik pengumpulan data yang dilakukan menggunakan kerangka kerja yang mampu menghasilkan temuan baru. Hal ini dilakukan untuk menemukenali ragam celah yang belum dilengkapi oleh penelitian sebelumnya. Oleh karena itu, tekni pengumpulan data yang dilakukan adalah wawancara mendalam terhadap individu dan kelompok (in-depth interviewing of individuals and small groups); observasi sistematis terhadap perilaku (systematic observation of behaviour); dan analisis dokumen (analysis of documentary data). Ketiga teknik tersebut merupakan bagian dari berbagai teknik yang terdapat dalam penelitian kualitatif (Darlington \& Scott, 2002:2).

Berdasarkan tema yang dikaji maka data penelitian menggunakan hasil wawancara, dokumen, catatan resmi, rekaman, korespondensi pribadi dan berbagai temuan terkait yang dapat digunakan sebagai perbandingan. Peran data tersebut adalah memberikan kutipan secara luas, mendeskripsikan secara rinci dan pengamatan terhadap peristiwa, fenomena, pengalaman atau perilaku yang ditemui, sehingga dapat memberikan deskripsi secara detail dan analisis mengenai kualitas atau isi dari suatu peristiwa (Marvasti, 2004:90). Sumber data berasal dari CIFOR, WWF, Basle Committee, Egmont Group, IBRA, FATF, IAIS, SKEPHI, PBB, PPATK, Greenpeace, buku (dalam format ebook), undang-undang dan peraturan lainnya, jurnal dan berbagai artikel media massa. 
Kompilasi berbagai data pembalakan liar dalam kaitannya dengan pencucian uang yang ditemukan disederhanakan menggunakan teknik analisis dokumen. Proses pelaksananaan penelitian terdiri atas pemilihan partisipan penelitian, pengumpulan data, analisis data penyusunan kerangka pemikiran (Marvasti, 2004:12). .Selanjutnya, pengamatan atas fenomena atau fakta empiris terkait hasil kejahatan pembalakan liar melalui pendekatan pencucian uang dianalisis menjadi kesimpulan yang bepotensi melahirkan alternatif alur pelacakan pelaku pembalakan liar.

\section{Pembalakan Liar dalam Konteks Kriminologi}

Konsep pembalakan liar (illegal logging) merujuk pada istilah yang kerap digunakan dalam berbagai forum dan diskusi untuk mendefinsikan serangkaian kegiatan ilegal terkait dengan ekosistem hutan, industri kehutanan, dan hasil hutan lainnya berupa kayu atau bukan kayu (timber and non-timber forest products/ NTFPs) (Tacconi, 2007:2). Definisi tersebut senada dengan yang diungkapkan oleh Sukardi (2003:73) yang menyatakan bahwa pembalakan liar adalah kegiatan di bidang kehutanan atau rangkaian kegiatan yang mencakup penebangan, pengangkutan, pengolahan hingga kegiatan jual beli (ekspor-impor) kayu yang tidak sah atau bertentangan dengan aturan hukum yang berlaku, atau yang dapat menimbulkan kerusakan hutan.

Pembalakan liar dapat dipahami sebagai rangkaian tindak kejahatan yang saling berhubungan di bidang kehutanan. Pembalakan liar adalah rangkaian kegiatan yang meliputi (Tacconi, 2007:4), yakni:

i. Pelanggaran terhadap hak masyarakat lokal dan umum dalam hal kepemilikan atas penguasaan hutan yang berlawanan dengan hukum kenegaraan, hukum sipil, hukum administrasi dan merupakan bentuk kejahatan;

ii. Pelanggaran Hak Pengusahaan Hutan (HPH) dan berbagai peraturan serta kesepakatan lainnya di bidang kehutanan;

iii. Kegiatan yang termasuk dalam illegal forest trade, antara lain pelanggaran peraturan tentang transportasi dan perdagangan atas hasil hutan, baik yang tergolong sebagai hasil hutan legal atau ilegal (legally or illegally harvested forest products);

iv. Kegiatan memproduksi hasil hutan, berupa kayu melalui industri dan memperdagangkannya. Pada kegiatan ini yang tergolong pembalakan liar jika kayu yang digunakan adalah kayu ilegal (illegally harvested logs); dan 
v. Kegiatan yang termasuk dalam illegal financial activities, antara lain pelanggaran dalam hal keuangan, pelaporan dan perpajakan yang berhubungan dengan hasil penjualan kayu, baik secara legal maupun ilegal.

Berdasarkan rangkaian tersebut, maka pembalakan liar merupakan bentuk kejahatan yang dijalankan secara terorganisir. Mengacu pada hal ini pembalakan liar dapat dikategorikan menjadi dua hal. Kategori pertama adalah pembalakan liar terbuka. Pembalakan liar terbuka dilakukan oleh pelaku secara terorganisir dan terencana berdasarkan pesanan tertentu (order). Kategori ini tergolong profesional, bermodal besar dan jangkauan pemasaran yang sangat luas. Kategori kedua adalah pembalakan liar tertutup. Pembalakan liar tertutup berupa kegiatan eksploitasi illegal dengan modus legal. Kategori ini dilakukan perusahaan resmi dengan cara manipulasi dokumen, surat keputusan dan foto citra satelit sebagai bukti sah tentang kerapatan dan potensi hasil hutan (Obidzinki dan Suramenggala, 2000:4-5).

Pembalakan liar dalam konteks kriminologi memuat unsur pelaku. Pelaku terbagi atas dua, yaitu individu dan korporasi. Pelaku individu adalah orang perseorangan, sedangkan yang dimaksud dengan korporasi adalah kumpulan orang atau kekayaan yang terorganisir baik merupakan badan hukum maupun yang tidak berbadan hukum (PPATK dan IWGFF, 2008). Pelaku individu antara lain:

a. Cukong (financial broker) adalah orang yang secara finansial mempunyai potensi untuk menggerakan aktivitas pembalakan liar, termasuk didalamnya pemilik sawmill liar.

b. Broker kayu adalah orang yang menjalankan peran penghubung antar pelaku pembalakan liar.

c. Backing adalah pihak yang menjalankan peran perlindungan terhadap aktivitas pembalakan liar, termasuk preman dan oknum tokoh masyarakat.

d. Politically exposed person (PEP) adalah orang yang popular secara politis yaitu individu yang merupakan atau dipercayakan dengan fungsi-fungsi yang dikenal umum di suatu negara (memiliki pengaruh), misalnya politisi, pejabat pemerintahan, aparat penegak hukum dan militer, eksekutif BUMN atau BUMD atau tokoh politik.

Sedangkan, pelaku korporasi dalam pembalakan liar mencakup:

a. Perusahaan pemegang konsensi kehutanan yang dikeluarkan oleh 
pejabat yang berwenang antara lain Izin Usaha Pemanfaatan Hasil Hutan Kayu-Hutan Alam (IUPHHK-HA) ${ }^{4}$, Izin Usaha Pemanfaatan Hasil Hutan Kayu-Hutan Tanaman (IUPHHK-HT) atau Izin Pemanfaatan Kayu (IPK).

b. Perusahaan pemegang konsensi atas izin Bupati atau Kepala Daerah antara lain Izin Pemanfaatan Kayu Tanah Milik (IPKTM), Izin Pemungutan Hasil Hutan Bukan Kayu (IPHBK), Hutan Tanaman Rakyat (HTR), Izin Pemungutan Hasil Hutan Kayu (IPHHK) dan IPK.

c. Industri kehutanan skala besar antara lain industri bubur kertas (pulp), industri chips, industri plywood, industri sawmill yang diduga menggunakan bahan baku (kayu) hasil pembalakan liar.

\section{Rezim Anti Pencucian Uang}

Pencucian uang merupakan aktivitas layaknya transaksi keuangan pada umumnya. Kegiatan tersebut berupa memasukkan uang ke dalam sistem keuangan, mentransfer uang, menginvestasikan ke berbagai instrumen keuangan, menukarkan dengan mata uang asing (valas), membeli portofolio saham, membeli berbagai barang mewah dan berinvestasi dalam berbagai bisnis lainnya.

${ }^{4}$ Dikenal juga dengan Hak Pengusahaan Hutan (HPH).
Perbedaanya terletak pada asal usul uang yang ditransaksikan dalam sistem keuangan. Pencucian uang dapat dipahami sebagai tindakan menyembunyikan atau menyamarkan uang hasil kejahatan dan mendistribusikan kembali uang tersebut kepada pelaku. Tujuan utama pencucian uang adalah menyamarkan dan menghilangkan asal usul uang hasil kejahatan (predicate offences) dan mendapatkan kembali uang tersebut dengan status legal (Stessen, 2003: 83).

Rezim anti pencucian uang lahir sebagai bentuk pencegahan dan penanggulangan maraknya aktivitas pencucian uang. Rezim ini lahir guna menjawab 9 tantangan dalam upaya memutus mata rantai yang menghidupi kejahatan (live bloods of crime). Pertama, globalisasi sistem keuangan yang memudahkan integrasi seluruh aktivitas keuangan. Kedua, kemajuan di bidang teknologi melalui maraknya pertumbuhan berbagai sistem keuangan. Ketiga, peraturan perbankan yang menganut kerahasian data nasabahnya. Keempat, kelonggaran aturan perbankan di beberapa negara yang tergolong surga pajak (tax haven countries). Kelima, kemunculan uang elektronik (e-money) dan perkembangan transaksi elektronik (ecommerce). Keenam, keberadaan profesi jasa pengelola keuangan. Ketujuh, adanya ketentuan hukum kerahasiaan hubungan 
kuasa hukum, pengelola keuangan dan klien. Kedelapan, semangat menjalankan rezim anti pencucian uang yang beragam di setiap negara. Kesembilan, ketentuan hukum di beberapa negara yang belum menjadikan pencucian uang sebagai tindakan kriminal.

Tantangan tersebut sejatinya memfokukan upaya "merubah" uang illegal menjadi legal. Uang ilegal merupakan input dalam kegiatan pencucian uang dan uang legal adalah output dari proses tersebut. Proses ini berupa kegiatan menempatkan uang ilegal ke dalam sistem keuangan (placement), memecahnya ke berbagai kegiatan keuangan (layering) dan menyatukannya kembali melalui bisnis legal (integration).

$\begin{array}{ccr} & \text { Kegiatan pertama yang dilakukan } \\ \text { dalam pencucian uang adalah }\end{array}$ menempatkan uang ilegal ke dalam sistem keuangan (placement). Pada tahap ini, pelaku pencucian uang memasukkan uang ilegal ke dalam sistem keuangan melalui lembaga keuangan atau lembaga nonkeuangan. Berdasarkan hal tersebut, maka dalam pencucian uang dikenal istilah pencuci uang aktif dan pencuci uang pasif (Setiono dan Husein, 2005). Pencuci uang aktif adalah pelaku pencucian uang yang secara aktif berusaha menyembunyikan atau mengaburkan sejumlah uang ilegal dengan menggunakan mekanisme dan instrumen lembaga keuangan. Sedangkan, pencuci uang pasif merupakan pihak-pihak yang membantu atau terlibat dalam pencucian uang. Pihak yang terlibat ini adalah orang-orang yang berkaitan dalam sistem keuangaan.

Setelah memasukkan uang ilegal ke dalam sistem keuangan, maka kegiatan selanjutnya adalah memecah uang dalam sistem keuangan tersebut dengan tujuan mengaburkan asal mula uang ilegal tersebut (layering). Layering meliputi seluruh kegiatan transaksi keuangan untuk merubah uang ilegal ke dalam berbagai bentuk dan membuatnya sulit dilacak. Layering dapat berupa kegiatan transfer keuangan ke beberapa rekening di berbagai bank yang terdapat di dalam atau luar negeri. Kegiatan ini dikenal juga dengan smurfing (Reuter dan Truman, 2004; Grosse, 2001).

$$
\text { Rekening tersebut dapat }
$$
mengatasnamakan sembarang nama atau bahkan menyembunykkan identitas nasabahnya (anonymous banking). Uang tersebut diambil dalam jumlah yang besar dan didepositokan ke berbagai rekening. Selain itu kegiatan lain yang dilakukan adalah dengan menukarkan dengan mata uang asing (money changer), membeli portofolio saham perusahaan dalam pasar bursa dan pengalihan pendapatan (transfer pricing). Tujuan layering adalah menyulitkan pelacakan uang hasil kejahatan (Grosse, 2001:3). 
Uang ilegal yang telah terpecah ke dalam berbagai bentuk tersebut kemudian disatukan kembali ke dalam bisnis legal (integration). Bisnis legal tersebut antara lain dinvestasikan pada bisnis properti (real-estate, apartement), restoran dan hiburan. Pada fase terakhir ini tingkat kesulitan untuk mengidentifikasi uang ilegal dan uang legal semakin tinggi (Alldridge, 2003).

\section{Perbedaan Pendekatan: Konvensional} dan Follow the Money

Perbedaan pendekatan pelacakan hasil kejahatan pembalakan liar dapat menjerat pelaku kejahatan utama (aktor intelektual). Hal ini dikarenakan arah pendekatan konvensional menyasar pelaku di lapangan yang berkaitan langsung dengan pembalakan liar. Pelaku dianalogikan kasat mata dan langsung berhubungan dengan barang bukti di TKP. Sedangkan, pendekatan follow the money dapat melacak ujung pangkal pelaku utama pembalakan liar. Pendekatan follow the money terbentur pada fakta bahwa pembalakan liar mayoritas disumbang oleh perusahaan berizin dan memiliki sertifikat ramah lingkungan (Nagara, 2007). Secara sederhana, perbedaan pendekatan kovensional dan follow the money dalam pelacakan hasil kejahatan pembalakan liar sebagai berikut :

\section{Perbedaan Pendekatan Konvensional dan Follow the Money dalam Pembalakan Liar}
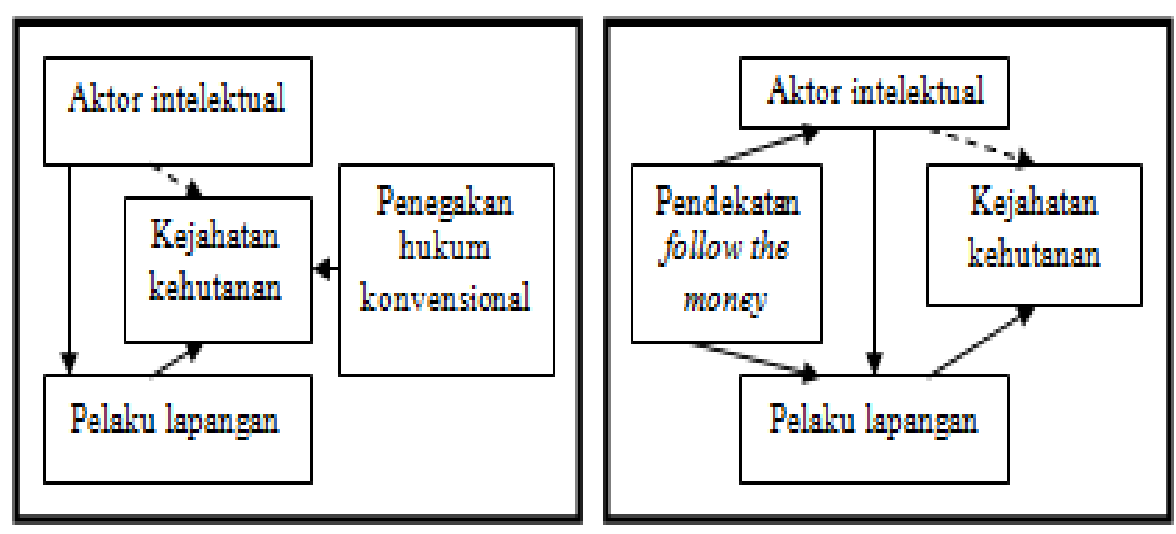

Sumber: diolah dari Nagara (2007:2) 
Alur Pelacakan Melalui Pendekatan Pencucian Uang

Pelacakan hasil kejahatan pembalakan liar melalui pendekatan tindak pidana pencucian uang dilakukan dengan menganalisis aktivitas placement, layering dan integration. Investigasi terhadap aliran dana hasil pembalakan liar menjadi target utama pelacakan. Karena keberadaan dana berperan sebagai sumber penghidupan kejahatan asal (live bloods of crime). Secara sederhana skema pencucian uang hasil pembalakan liar adalah sebagai berikut :

\section{Alur Pencucian Uang Hasil Pembalakan Liar}

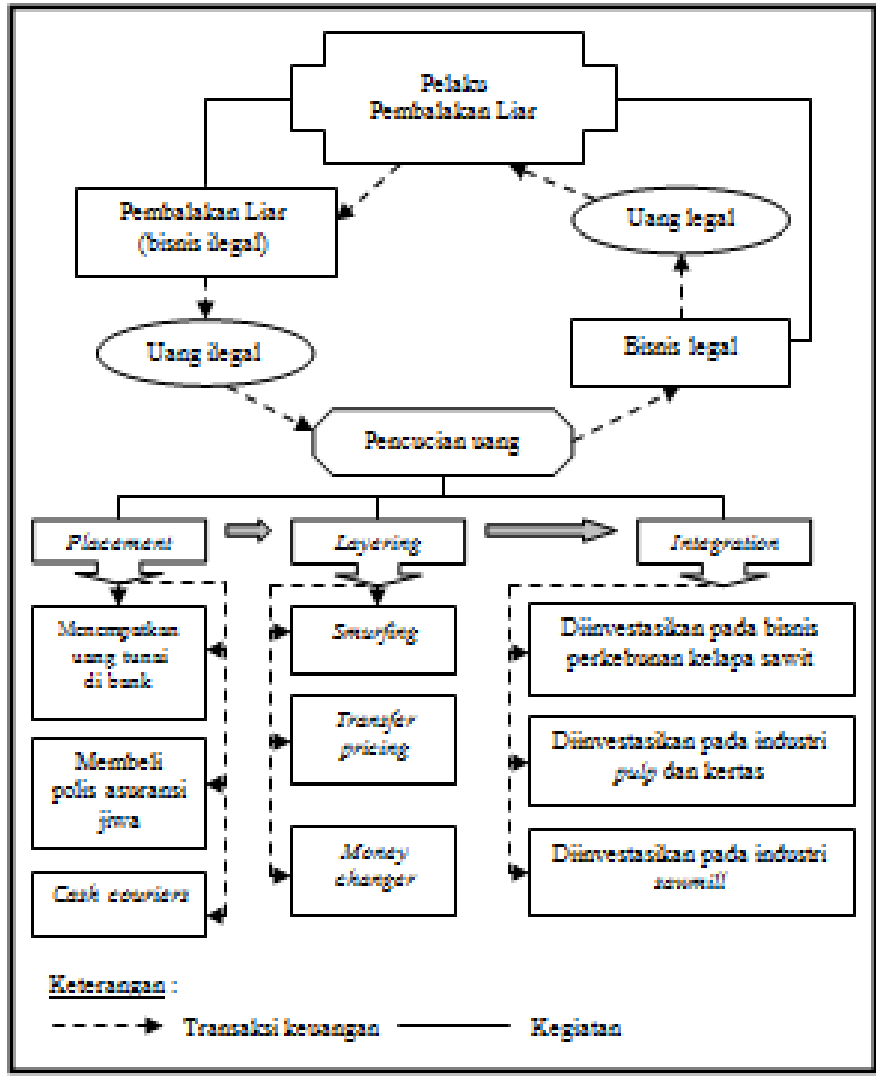

Sumber: diolah dari Nurhadiyanto (2010). 


\section{Placement}

Tindakan placement dengan menempatkan uang hasil kejahatan pembalakan liar ke dalam sistem keuangan. Modus yang dilakukan adalah menempatkan uang tunai atau cek hasil transaksi pembalakan liar ke Lembaga Jasa Keuangan (LJK) atau digunakan untuk membeli polis asuransi. Modus pertama yakni LJK, khususnya lembaga perbankan adalah kekuatan utama dalam memfasilitasi pencucian uang hasil pembalakan liar (Setiono dan Husein, 2005). Kegiatan menempatkan uang hasil pembalakan liar melalui lembaga perbankan dilakukan dengan cara mengkredit rekening di bank (Nasution, 2004).

Modus kedua lembaga asuransi menjadi bagain placement hasil pembalakan liar. Modus yang dilakukan para penyokong dana adalah dengan membeli polis asuransi dalam jumlah yang besar. Kemudian dalam kurun waktu singkat, polis asuransi jiwa tersebut dibatalkan atau diajukan klaim. Konsekuensi dari kegiatan ini berupa hukuman (penalty) pemotongan biaya administrasi oleh lembaga asuransi tersebut (Srikandi, 2009).

Modus ketiga dengan transaksi uang tunai yang dipecah dalam berbagai mata uang asing (cash smuggling). Cara ini dianggap sebagai the oldest placement techniques, namun menjadi modus yang tergolong efektif. Hal ini sulit terdeteksi karena tidak melalui sistem keuangan di LJK (Savona, 2005:24).

\section{Layering}

Tindakan kedua yaitu layering berupa proses melapisi, memindahkan atau mengubah uang hasil pembalakan liar melalui berbagai transaksi keuangan yang kompleks. Hal ini guna mempersulit pelacakan asal usul dana. Modus yang dilakukan, antara lain: a) uang hasil pembalakan liar ditansfer antar rekening, ditukarkan dengan mata uang asing atau diinvestasikan dalam portofolio saham; b) memperoleh uang, menerima pembayaran atau transfer, atau membeli barang dan jasa dengan cara menjual kayu hasil curian dengan menggunakan dokumen Surat Keterangan Sahnya Hasil Hutan (SKSHH) atau mencampur kayu ilegal dengan kayu legal dan menjualnya dengan SKSHH seolah-olah kayu legal.

Modus pertama dikenal sebagai smurfing yakni melakukan transfer uang hasil pembalakan liar ke berbagai rekening di bank yang terdapat di dalam atau luar negeri. Beragamnya mekanisme dan instrumen keuangan yang ditawarkan lembaga perbankan, semakin memudakan penyokong dana untuk mentransfer uang ilegal hasil pembalakan liar ke berbagai 
rekening. Rekening-rekening yang menjadi tujuan pentransferan adalah rekening milik para pelaku lain, karyawan atau kerabat dan keluarga (Srikandi, 2009). Ragam instrumen keungan yang digunakan antara lain investment banking, currency exchange, commodities broking, cash management, letters of credit, confidential numbered accounts, arbitrage, issue of financial guarantees, third-party loans, trust formation, sale and exchange of investments, dan export and trade funding (Lilley, 2006: 101).

Modus kedua transfer pricing yakni kemampuan organisasi pembalakan liar mentransfer pendapatan hasil kayu mereka ke perusahaan-perusahaan afiliasi yang beresiko dan berjurisdiksi tinggi. Perusahaan afiliasi ini dapat berbentuk shell company atau paper company. Shell company merupakan bentuk perusahaan afiliasi layaknya perusahaan cabang. Sedangkan, paper company adalah perusahaan afiliasi fiktif atas dasar suratsurat lisensi bisnis semata (Srikandi, 2009). Kegiatan transfer pricing berupa kegagalan menagih kredit dagang atau pinjaman dari perusahaan-perusahaan beresiko tinggi. Penyokong dana pembalakan liar juga dapat menggelembungkan biaya produksi, termasuk harga kayu yang disediakan oleh perusahaan-perusahaan yang berafiliasi tersebut. Kegiatan lainnya berupa pembelian saham perusahaan-perusahaan afiliasi dengan harga yang tidak masuk akal didukung oleh penilaian saham oleh penilai independen (Setiono \& Husein, 2005:8-9). Modus ketiga adalah money changer dengan menukarkan mata uang negara lokasi pembalakan liar dengan mata uang internasional, umumnya dalam dollar Amerika (USD) (Novian, 2009).

\section{Integration}

Tindakan ketiga yaitu integration berupa upaya mengembalikan dana yang telah tampak sah kepada pemiliknya, sehingga dapat digunakan dengan aman tanpa terlacak asal usulnya. Modus yang dilakukan antara lain: a) menginvestasikan uang hasil pembalakan liar dalam berbagai bisnis; b) menjalankan bisnis kehutanan dengan menggunakan bahan baku kayu dari hasil penebangan ilegal atau memperoleh dana modal kerja dengan cara melawan hukum seperti penyuapan, penipuan, penggelapan, dan kejahatan perbankan.

Modus pertama yakni investasi pada bisnis perkebunan kelapa sawit. Kelapa sawit menjadi pilihan karena memiliki nilai ekonomis yang tinggi sebagai penghasil minyak kelapa sawit (crude palm oil/ CPO) dan merupakan salah satu komoditi perdagangan dunia yang mahal harganya (Srikandi, 2009). Modus kedua adalah investasi pada 
industri bubur kayu (pulp) dan kertas. Modus industri pulp antara lain dengan mencampur kayu hasil pembalakan liar dengan kayu legal untuk diolah dalam proses yang sama (Setiono dan Husein, 2005). Modus ketiga yaitu investasi pada industri penggergajian kayu (sawmill). Uang hasil pembalakan liar diinvestasikan pada industri sawmill yang memiliki perizinan legal (Tempo, 2006).

\section{Kesimpulan}

Pelacakan pembalakan liar (illegal logging) melalui pendekatan pencucian uang menjadi salah satu cara yang efektif dalam menjerat aktor intelektual. Satusatunya cara untuk membuktikan keterlibatan mereka dalam kegiatan pembalakan liar adalah dari sisi pendekatan terhadap aliran dana. Para pelaku di balik layar tersebut memiliki modal yang membuat bisnis kehutanan mudah dikendalikan. Tak hanya, di wilayah tempat pembalakan liar berlangsung tetapi dapat pula dilakukan di kota-kota besar yang jauh dari wilayah pembalakan liar atau di luar negeri. Untuk menggerakkan bisnisnya perlu memanfaatkan sistem keuangan melalui LJK, jasa akuntan dan kuasa hukum. Para cukong dan aktor intelektual akan mendapatkan uang atau kekayaan hasil pembalakan liar berupa uang yang tidak sah atau uang ilegal. Oleh karena itu, untuk menjadikan uang tersebut nampak seolaholah berasal dari sumber legal maka perlu dilakukan upaya untuk mengubah uang tersebut menjadi uang yang nampak bersih. Tujuannya agar menyulitkan pelacakan dan pendeteksian asal usul uang tersebut (predicate offenses).

Sejalan dengan hal ini, upaya penegakkan hukum pembalakan liar seringkali berhadapan dengan perusahaanperusahaan yang telah mengantongi izin legal dan telah mendapat label sertifikat ramah lingkungan. Oleh karena itu, pendekatan follow the money menjadi alternatif utama upaya pemberantasan pembalakan liar. Pendekatan pencucian uang dapat melacak aliran dana para aktor inetelektual, mulai dari placement, layering dan integration. Sehingga tidak hanya menjerat para pelaku di lapangan namun dapat turut menyeret para aktor intelektual di balik pembalakan liar.

\section{Daftar Referensi}

Alexander, Harry. (2006). Tindak Pidana Kehutanan Terkait Dengan Undang-Undang Tindak Pidana Pencucian Uang. Depok: Pascasarjana Fakultas Hukum Universitas Indonesia.

Alldridge, Peter. (2003). Money Laundering Law: Forfeiture, Confiscation, Civil Recovery, Criminal Laundering and Taxation of the Proceeds of Crime. Oxford: Hart Publishing. 
Atmasasmita, Romli. (25 Juni 2008). Efektivitas Penerapan Undangundang Tindak Pidana Pencucian Uang dalam Illegal Logging dalam Seminar Penyidikan Tindak Pidana Kehutanan dan Penerapan UU Tindak Pidana Pencucian Uang, Jakarta.

Danuri, Bambang Hendarso. (25 Juni 2008). Strategi Penyidikan Terhadap Perkara Tindak Pidana Kehutanan (Illegal Logging) dan Penerapan Undang-undang Tindak Pidana Pencucian Uang (Money Laundering) dalam Seminar Penyidikan Tindak Pidana Kehutanan dan Penerapan UU Tindak Pidana Pencucian Uang, Jakarta.

Darlington, Yvonne \& Scott, Dorothy. (2002). Qualitative Research in Practice: Stories from the Field. Crows Nest: Allen \& Unwin.

Flick, U., von Kardorff, E., \& Steinke, Ines. (Eds.). (2004). A Companion to Qualitative Research. London: Sage Publications.

Husein, Yunus. (5-6 Mei 2004). Pencegahan dan Pemberantasan TPPU di Indonesia dalam Lokakarya Terbatas Tentang Tindak Pidana Pencucian Uang, Graha Niaga, Jakarta.

Husein, Yunus. (25 Juni 2008). Penerapan UU Tindak Pidana Pencucian Uang dari Tindak Pidana di Bidang Kehutanan Illegal Logging dalam Seminar Penyidikan Perkara Tindak Pidana Kehutanan (Illegal Logging) dan Penerapan Undang-undang Tindak Pidana Pencucian Uang (Money Laundering), Jakarta.

Lilley, Peter. (2006). Dirty Dealing: The Untold Truth About Global Money Laundering, International Crime and Terrorism. (ed. ke-3). London: Kogan Page.
Marvasti, Amir B. (2004). Qualitative Research in Sociology. London: Sage Publications.

McCarthy, John F. (2002). Power and Interest on Sumatra's Rainforest Frontier: Clientelist Coalitions, Illegal Logging and Conservation in the Alas Valley dimuat dalam Journal of Southest Asian Studies, Vol. 33, No. 1 (Feb., 2002), 77106.

Nagara, Grahat. (2007). Rezim Anti Pencucian Uang dalam Kejahatan Kehutanan. ELSDA Institute.

Nasution, Bismar. (6 Mei 2004). Rezim Anti Money Laundering untuk Memberantas Kejahatan di Bidang Kehutanan dalam Seminar Pemberantasan Kejahatan Hutan Melalui Penerapan Undangundang Tindak Pidana Pencucian Uang, Medan.

Novian, Muhammad \& Srikandi, Ferti. PPATK. (15 Mei 2009). Wawancara.

Nurhadiyanto, Lucky. (2010). Pola Pencucian Uang Hasil Perdagangan Narkoba dan Pembalakan Liar dimuat dalam Jurnal Kriminologi Indonesia, Vol. 6, No.2.

Obidzinki, Krystof \& Suramenggala, Iman. (2000). Informal Logging in East Kalimantan: Social, Economics and Political Implications. Bogor: Center for International Forestry Research.

Paripurna, Garda T. \& Kongah, Natsir. (9 Juni 2004). Menggunakan Undangundang Tindak Pidana Pencucian Uang dalam Mengatasi Kejahatan Kehutanan dalam Diskusi Menggunakan UU Anti Pencucian Uang untuk Mengatasi Kejahatan Kehutanan di Riau, Riau. 
Pusat Pelaporan dan Analisis Transaksi Keuangan \& Indonesian Working Group on Forest Finance. (2008). Pedoman Pemberian Informasi Tindak Pidana Pencucian Uang di Bidang Kehutanan dan Konservasi Sumber Daya Alam Hayati. Jakarta: PPATK \& IWGFF.

Savona, Ernesto Ugo. (Ed.). (2005). Responding to Money Laundering: International Perspectives. Amsterdam: Taylor \& Francis.

Setiono, Bambang. (2004). Debt Settlements of Indonesia Forestry Conglomerates. CIFOR Governance Series. Bogor: Center for International Forestry Research.

Setiono, Bambang. (2004). Impacts of the Decentralization Policy on Timber Industry Performance. CIFOR Working Paper. Bogor: Center for International Forestry Research.

Setiono, Bambang \& Husein, Yunus. (2005). Memerangi Kejahatan Kehutanan dan Mendorong Prinsip Kehati-hatian Perbankan untuk Mewujudkan Pengelolaan Hutan yang Berkelanjutan: Pendekatan Pencucian Uang. CIFOR Occasional Paper. (no. 44 (i)). Bogor: Center for International Forestry Research.

SKEPHI. (28 Desember 2007). Refleksi Akhir Tahun 2007: Perusakan Hutan Gagal Dicegah dan Dikurangi. Jakarta: SKEPHI.

Sukardi. (2005). Illegal Logging dalam Perspektif Politik Hukum Pidana (Kasus Papua). Yogyakarta: Penerbitan Universitas Atma Jaya Yogyakarta.

Wakker, E., Gelder, W. J. dan Telapak Sawit. (2000). Funding Forest Destruction: The Involvement of Dutch Banks in the Financing of Oil Palm Plantation in Indonesia. A Report for Greenpeace. Belanda. 